\title{
PERLINDUNGAN HUKUM BAGI KREDITUR DALAM PERJANJIAN FIDUSIA
}

\author{
Moya Nurmelinda \\ Pasca Sarjana Universitas Islam NUsantara \\ Email: moyanurmelinda@gmail.com,
}

\begin{abstract}
Fiduciary is the transfer of ownership rights to an object on the basis of trust provided that the object whose ownership rights are transferred remains in the control of the owner of the object. While the Fiduciary guarantee in accordance with Article 1 paragraph 2 of Law no. 42 of 1999 is a security right on a movable object, both tangible and intangible and immovable objects, especially buildings that cannot be encumbered with mortgage rights. Research Methods in this scientific papers using normative juridical research methods. As well as using data collection techniques carried out using descriptive analysis techniques, with secondary data sources, which include primary legal materials such as laws and regulations relating to fiduciary and mortgage rights. The results in this research can be explained that as referred to in Act No. 4 of 1996 concerning Mortgage Rights which remains in the control of the fiduciary, as collateral for the repayment of certain debts and gives priority to other creditors. Fiduciary guarantees can be carried out and stipulated in a fiduciary certificate which is authorized by a notary. With this certificate, it can also be used as a protection for both parties, both as a borrower and as a lender, no one is harmed.
\end{abstract}

\section{Keywords: Collateral, Fiduciary, Creditor, Debitor}

\section{PENDAHULUAN}

Secara historis lembaga fidusia dalam bentuk klasik sudah ditemukan sejak zaman Romawi. Dalam hal ini, di Romawi terdapat apa yang disebut dengan Fidusia Cum crediture, konstruksi hukum dimana barang-barang debitur diserahkan miliknya kepada kreditur, tetapi dimaksudkan hanya sebagai jaminan hutang ${ }^{1}$. Bersamaan dengan itu, di Romawi terdapat pula apa yang disebut dengan Fidusia Cum Amico, tetapi dalam hal ini hanya dimaksudkan sebagai pengangkatan seorang wakil untuk memelihara kepentingannya. Jadi tidak ada penyerahan hak milik atau jaminan hutang sebagaimana dilakukan dalam pengikatan fidusia saat ini ${ }^{2}$.

Setelah Bierbrouwerij Arrest di negeri Belanda (Nederland), kemudian pada tahun 1932 barulah terdapat petunjuk bahwa di Indonesia juga mengikuti praktek di

\footnotetext{
1 Sri Soedewi Masjchun, Hukum Jaminan di Indonesia Pokok-pokok Hukum Jaminan dan Jaminan Perorangan, Liberty, Yogyakarta, 1980, hlm. 74.

2 Munir Fuady, Jaminan Fidusia, PT. Citra Aditya Bakti. Bandung, 2000, hlm. 8.
} 


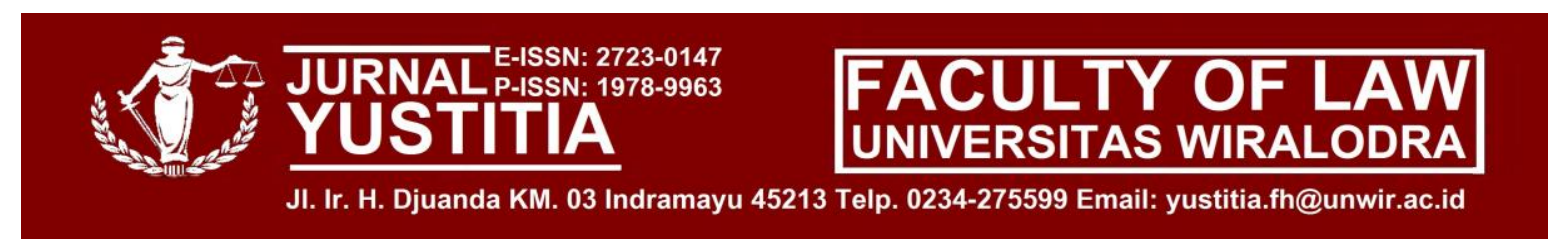

Belanda mengenai fidusia. Yaitu dengan adanya keputusan Hoogerechtshof (HGH), tanggal 18 Agustus 1932, merupakan kasus yang dikenal dengan sebutan BPM Arrest. Putusan ini merupakan suatu tonggak dimulainya perkembangan fidusia di Indonesia ${ }^{3}$.

Setelah itu Jaminan Fidusia digunakan di Indonesia sejak zaman penjajahan Belanda sabagai suatu bentuk jaminan yang lahir dari yuriprudensi ${ }^{4}$. Bentuk jaminan ini digunakan secara luas dalam transaksi pinjam meminjam karena proses pembebanannya dianggap sederhana, mudah dan cepat, tetapi tidak menjamin adanya kepastian hukum, karena dapat saja debitur menjaminkan benda yang telah dibebani dengan Fidusia kepada pihak lain tanpa sepengetahuan penerima Fidusia ${ }^{5}$.

Lembaga Jaminan Fidusia telah diakui eksistensinva dengan adanya Undang-undang Republik Indonesia Nomor: 42 tahun 1999 tentang Jaminan Fidusia, yang telah diundangkan pada tanggal 30 September 1999. Sebagaimana diketahui bahwa jaminan Fidusia adalah hak agunan/jaminan atas benda bergerak yang berwujud maupun tidak berwujud, atau yang tidak dapat dibebani hak tanggungan menurut Undang-undang No. 4 tahun 1996 tentang Hak Tanggungan yang dimiliki oleh Penerima Fidusia yang terdaftar di Kantor Pendaftaran Fidusia, yaitu sebagai agunan bagi pelunasan utang tertentu dan yang mempunyai hak untuk didahulukan daripada para kreditor lainnya.

Sedangkan Fidusia adalah pengalihan hak kepemilikan atas suatu benda yang dapat difidusiakan tersebut berdasarkan kepercayaan yang penguasaannya tetap dilakukan oleh si pemilik benda tersebut. Biasanya hal terjadi karena pemilik benda tersebut (debitor) membutuhkan sejumlah uang dan sebagai jaminan atas pelunasan utangnya tersebut si debitor menyerahkan secara kepercayaan hak kepemilikannya atas suatu benda bergerak atau benda yang tidak termasuk dalam lingkup Undang-Undang No. 4 tahun 1996 kepada kreditomya; dan hak tersebut juga dapat dialihkan kepada pihak lain.

Jaminan Fidusia merupakan lembaga jaminan yang sangat dibutuhkan dalam dunia perbankan, mengingat bank adalah lembaga keuangan yang dapat menghimpun dan menyalurkan dana masyarakat untuk mendukung pertumbuhan ekonomi. Bank dapat dikatakan sebagai urat nadi perekonomian suatu negara, oleh karena itu perkembangan dunia

\footnotetext{
3 Purwahid Patrik dan Kashadi, Hukum Jaminan Edisi Revisi dengan UUHT, Fakultas Hukum Universitas Diponegoro, Semarang, 1997, hlm. 40.

4 A. Hamzah \& Senjun Manulung, Lembaga Fidusia dan Penerapannya di Indonesia, Indhill-Co, Jakarta, 1987, hlm. 24.

5 Kashadi, Hukum Jaminan, Fakultas Hukum Universitas Diponegoro, Semarang, 2000, hlm. 59.
} 


\section{(1)

perbankan dapat menjadi indikator kemajuan perekonomian negara yang bersangkutan. Semakin maju suatu negara, maka semakin besar peranan perbankan dalam mengendalikan negara tersebut. Artinya keberadaan dunia perbankan semakin dibutuhkan pemerintah dan masyarakat negara tersebut.

Penyaluran kredit kepada masyarakat merupakan usaha yang terpenting bank dalam menjalankan fungsinya sebagai lembaga keuangan. Kredit berdasarkan Pasal 1 angka 11 Undang-Undang Nomor 10 Tahun 1998 tentang Perubahan Undang-Undang Nomor 7 Tahun 1992 tentang Perbankan merupakan upaya penyediaan uang atau tagihan yang dapat dipersamakan dengan itu, berdasarkan persetujuan atau kesepakatan pinjam-meminjam antara bank dengan pihak lain yang mewajibkan pihak peminjam untuk melunasi utangnya setelah jangka waktu tertentu dengan pemberian bunga.

Adapun pemberian kredit itu dilakukan baik dengan dana-dana yang dipercayakan pihak ke-3 (ketiga) maupun dengan jalan memperedarkan alat-alat pembayaran baru berupa uang giral ${ }^{6}$. Penyaluran kredit merupakan kegiatan yang beresiko bagi bank oleh karena itu perlu diimbangi dengan adanya ketentuan hukum jaminan yang jelas dan lengkap, mengingat setiap penyaluran kredit memerlukan jaminan yang kuat. Dengan dibuatnya Undang-Undang No. 42 Tahun 1999 tentang Jaminan Fidusia ini dimaksudkan untuk membantu kegiatan usaha dan untuk memberikan kepastian hukum kepada para pihak yang berkepentingan, terutama dalam dunia perbankan.

Dalam Undang-Undang Nomor 42 tahun 1999 tentang Fidusia, juga mengatur tentang proses pendaftaran fidusia, pendaftaran jaminan fidusia di Kantor Pendaftaran Fidusia merupakan suatu hal yang sangat penting, mengingat dengan didaftarkannya Jaminan Fidusia tersebut, maka secara yuridis Jaminan Fidusia tersebut lahir dan akan diikuti dengan diterbitkannya Sertifikat Jaminan Fidusia yang mengandung Titel Eksekutorial yang berkekuatan sama dengan Putusan Pengadilan yang berkekuatan hukum tetap. Sertifikat Jaminan Fidusia yang memiliki kekuatan eksekutorial sangat diperlukan untuk melakukan eksekusi Jaminan Fidusia.

Pasal 11 ayat (1) Undang-Undang Nomor 42 tahun 1999 tentang Fidusia menyebutkan bahwa benda yang dibebani dengan jaminan fidusia tersebut wajib didaftarkan. Pendaftaran jaminan fidusia dilaksanakan di tempat kedudukan pemberi fidusia,

\footnotetext{
${ }^{6}$ Muhammad Djumhana, Hukum Perbankan di Indonesia, Citra Aditya Bakti, Bandung. 1998, hlm.77.
} 


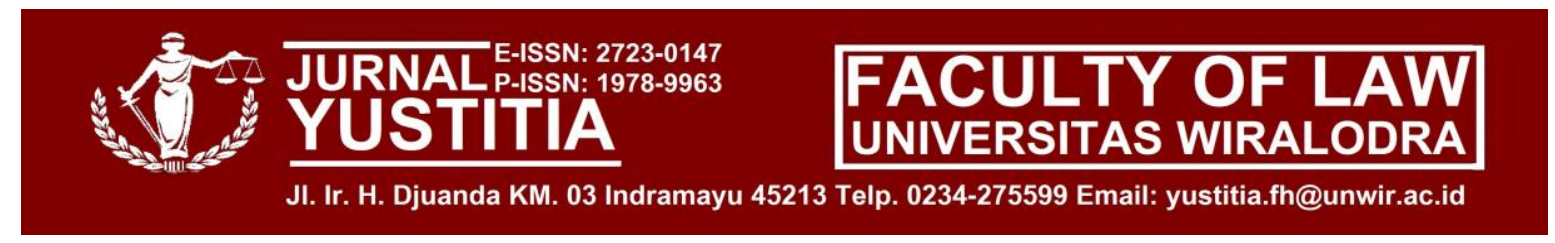

dan pendaftarannya mencakup benda, baik yang berada di dalam maupun di luar wilayah Republik Indonesia untuk memenuhi asas publisitas dan menjamin kepastian terhadap kreditor lainnya. Namun tidak ditentukan lebih lanjut batasan waktu untuk pendaftaran jaminan fidusia. Salah satu ciri jaminan hutang yang modern adalah terpenuhinya unsur publisitas. Maksudnya semakin terpublikasi jaminan hutang, akan semakin baik, sehingga kreditur atau khalayak ramai dapat mengetahuinya atau punya akses untuk mengetahui informasi-informasi penting di sekitar jaminan hutang tersebut. Asas publisitas ini menjadi sangat penting terhadap jaminan-jaminan hutang yang fisik obyek jaminannya tidak diserahkan kepada kreditur, seperti Jaminan Fidusia misalnya.

Pada praktik permasalahan-permasalahan yang terjadi dalam perjanjian fidusia dilapangan antara lain; tidak dilakukannya pendaftaran benda fidusia (hanya berhenti pada pembuatan akta otentik), dilakukannya negosiasi yang memberikan biaya tambahan bagi penerima fidusia pada saat mengeksekusi benda jamainan fidusia, sehingga sertifikat fidusia tidak memberikan pendidikan hukum dalam masyarakat (permasalahan eksekusi dari jaminan fidusia).

\section{IDENTIFIKASI MASALAH}

Berdasarkan hal-hal yang telah diuraikan diatas, maka permasalahan yang hendak dikemukakan dalam penulisan tesis ini adalah sebagai berikut :

1. Bagaimana Perlindungan Hukum Bagi Kreditur dalam Perjanjian Fidusia Berdasarkan Undang-Undang Nomor 43 Tahun 1999 Tentang Fidusia?

2. Apa hambatan-hambatan pelaksanaan perjanjian kredit dengan jaminan fidusia dalam praktiknya?

\section{METODE}

Metode Pendekatan yang digunakan adalah yuridis normatif yaitu penelitian hukum yang mempergunakan sumber data sekunder ${ }^{7}$, dengan menyusun kerangka konsepsional, dengan merumuskan ketentuan yang terdapat dalam Peraturan Perundang-undangan yang menjadi dasar penelitian ${ }^{8}$. Spesifikasi Penelitian yang digunakan dalam Penelitian ini

\footnotetext{
7 Ronny Hanitijo Soemitro, Metodologi Penelitian Hukum dan Jurimetri, Galia Indonesia, cet. ke-4, Jakarta, 1990, hlm. 30.

8 Amirudin “et.al” Pengantar Metode Penelitian Hukum, Raja Grafindo Persada, Jakarta, 2000, hlm.119.
} 


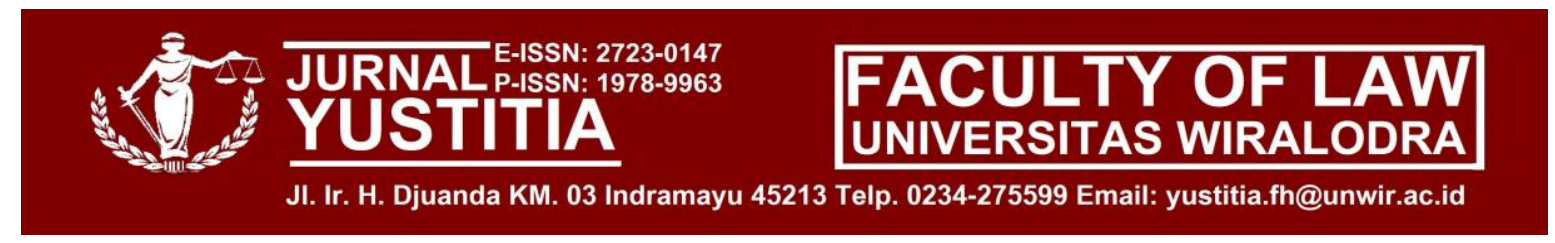

dilakukan secara deskriptif-analitis yaitu penelitian yang menggambarkan peristiwa yang sedang diteliti dan kemudian menganalisanya berdasarkan fakta-fakta berupa data sekunder yang diperoleh dari bahan hukum primer, bahan hukum sekunder dan bahan hukum tersier 9 Penelitian ini dilakukan dalam dua tahap, yaitu penelitian kepustakaan (library research) dan pengumpulan data lapangan. Penelitian Kepustakaan (library research) digunakan untuk memperoleh data dalam penelitian ini yaitu: bahan hukum primer, bahan hukum sekunder dan bahan hukum tersier ${ }^{10}$. Metode analisis data yang digunakan dalam penelitian ini adalah metode analisis yuridis normatif kualitatif.

\section{HASIL DAN PEMBAHASAN}

\section{A. Perlindungan Hukum Bagi Kreditur dalam Perjanjian Fidusia Berdasarkan Undang-Undang Nomor 43 Tahun 1999 Tentang Fidusia}

Salah satu cara untuk melindungi kepentingan Kreditur (sebagai Fidusia) adalah dengan memberikan ketentuan yang pasti akan Kreditur. Diatumya data yang lengkap yang harus termuat dalam jaminan Fidusia (Pasal 6 Undang-Undang Nomor 43 Tahun 1999 Tentang Fidusia), secara tidak langsung memberikan pegangan yang kuat bagi Kreditur sebagai Penerima Fidusia, khususnya tagihan mana yang dijamin dan besamya nilai jaminan, yang menentukan seberapa besar tagihan kreditur preferen.

Perlindungan hukum dan kepentingan kreditur dalam Undang-Undang Nomor 43 Tahun 1999 Tentang Fidusia dapat dilihat pada Pasal 20 Undang-Undang Nomor 43 Tahun 1999 Tentang Fidusia :

"Fidusia tetap mengikuti Benda yang menjadi objek Jaminan fidusia dalam tangan siapapun Benda tersebut berada, kecuali pengalihan atas benda tersebut, kecuali pengalihan atas benda persediaan yang monjadi objek Jaminan Fidusia"

Ketentuan menegaskan bahwa jaminan fidusia mempunyai sifat kebendaan dan berlaku terhadapnya asas droit de suite, kecuali pengalihan atas benda persediaan yang menjadi objek jaminan fidusia.

Perlindungan yang sama juga dapat dilihat dalam Pasal 23 ayat (2) Undang-Undang Nomor 43 Tahun 1999 Tentang Fidusia :

"Pemberi Fidusia dilarang mengalihkan, menggadaikan, atau menyewakan kepada pihak lain Benda yang menjadi objek jaminan Fidusia yang tidak merupakan benda

\footnotetext{
9 Soerjono Soekanto, Pengantar Penelitian Hukum, Grafindo, Jakarta, 2006, hlm. 10.

${ }^{10}$ Sunaryati Hartono, "Kembali ke Metode Penelitian Hukum", dalam Bunga Rampai Metodologi Penelitian dan Penulisan Karya Ilmiah Hukum, Koko Kosidin (Ed), 1990, hlm. 4.
} 


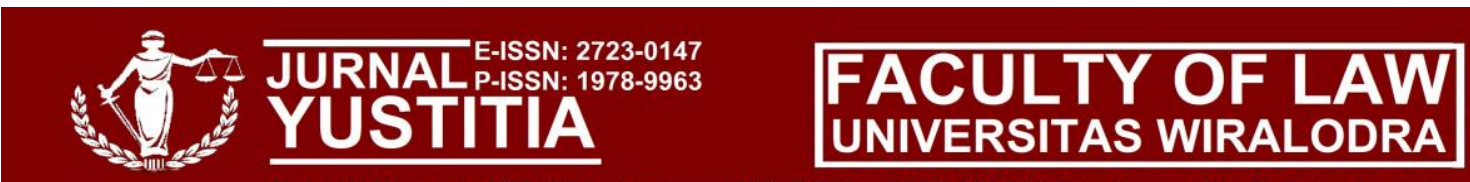

JI. Ir. H. Djuanda KM. 03 Indramayu 45213 Telp. 0234-275599 Email: yustitia.fh@unwir.ac.id

persediaan, kecuali dengan persetujuan tertulis terlebih dahulu dan Penerima Fidusia".

Sanksi terhadap ketentuan di atas adalah pidana sebagaimana dimaksud dalam Pasal 36 Undang-Undang Nomor 43 Tahun 1999 Tentang Fidusia :

"Setiap orang dengan sengaja memalsukan, mengubah, menghilangkan atau dengan cara apapun memberikan keterangan secara menyesatkan, yang jika hal tersebut diketahui oleh salah satu pihak tidak melahirkan perjanjian jaminan fidusia, dipidana dengan pidana penjara paling singkat 1 (satu) tahun dan paling lama 5 (lima) tahun dan denda paling sedikit Rp.10.000.000.- (seputuhjuta rupiah) dan paling banyak Rp. 100.000.000.- (seratus juta rupiah)"

Atas segala tindakan dan kelalaian pemberi fidusia, penerima fidusia berdasarkan karena kelalaian tersebut tidak bertanggung jawab, sebagamana dimaksud dalam Pasal 24 Undang-Undang Nomor 43 Tahun 1999 Tentang Fidusia :

"Penerima Fidusia tidak menanggung kewajiban atas akibat tindakan atau kelalaian Pemberi Fidusia baik yang timbul dari hubungan kontraktual atau yang timbul dari perbuatan melanggar hukum sehubungan dengan penggunaan dan pengalihan Benda yang menjadi objek Jaminan Fidusia".

Pada intinya maksud/tujuan dari perjanjian jaminan fidusia dari segi perlindungan hukum bagi kreditur adalah memberikan hak istimewa atau hak didahulukan baginya guna pelunasan hutang-hutang, debitur padanya asas schuld dan haftung.

Lebih jauh perlindungan hukum terhadap hak atas piutang yang didahulukan dapat dilihat pada ketentuan Pasal 27 Undang-Undang Nomor 43 Tahun 1999 Tentang Fidusia :

1) Penerima Fidusia memiliki hak yang didahulukan terhadap kreditor lainnya.

2) Hak didahulukan sebagaimana, dimaksud dalam ayat (1) adalah hak Penerima Fidusia untuk mengambil pelunasan piutangnya atas hasil eksekusi Benda yang menjadi objek Jaminan Fidusia.

3) Hak yang didahulukan dan Penerima Fidusia tidak hapus karena adanya kepailitan dan atau likuidasi Pemberi Fidusia.

Secara keseluruhan maka, beberapa hal yang dapat menunjukkan adanya perlindungan hukum terhadap kreditur (Penerima Fidusia) menurut Undang-Undang Nomor 43 Tahun 1999 Tentang Fidusia antara lain sebagai berikut:

a. Adanya lembaga pendaftaran jaminan fidusia, yang tidak lain adalah untuk menjamin kepentingan pihak yang menerima fidusia;

b. Adanya larangan pemberi fidusia untuk memfidusiakan ulang obyek jaminan fidusia (pasal 17);

c. Adanya ketentuan bahwa Pemberi Fidusia tidak diperbolehkan untuk mengalihkan, menggadaikan atau menyewakan (pasal 23 Sub 2); 
d. Adanya ketentuan pemberi fidusia wajib menyerahkan benda jaminan, kalau kreditur hendak melaksanakan eksekusi atas obyek jaminan fidusia;

e. Adanya ketentuan pidana dalam Undang-undang Jaminan Fidusia.

Dasar pelaksanaan Pendaftaran jaminan fidusia :

1) Undang-Undang Nomor 43 Tahun 1999 Tentang Fidusia (Lembaran Negara Tahun 1999 Nomor 168, Tambahan Lembaran Negara Nomor 3889);

2) Peraturan Pemerintah RI Nomor 86 Tahun 2000 tentang Tata Cara Pendaftaran jaminan Fidusia;

3) Keputusan Presiden RI Nomor 139 Tahun 2000 tentang Pembentukan Kantor Pendaftaran Fidusia di setiap lbukota Propinsi di Wilayah Negara. Republik Indonesia

4) Keputusan Menteri Kehakiman dan Hak asasi Manusia RI Nomor M.08PR.07.01 Tahun 2000 tentang Pembukaan Kantor Pendaftaran Fidusia;

Berdasarkan Pasal 12 Ayat (1) Undang-Undang Nomor 43 Tahun 1999 Tentang Fidusia pelaksanaan Pendaftaran Jaminan Fidusia dilakukan pada Kantor Pendaftaran Fidusia (KPF), Kantor Pendaftaran Fidusia sebagaimana dimaksud berada dalam lingkup tugas Kementrian Hukum dan HAM (Pasal 12 Ayat (3)), yang sekarang pelaksanaannya dilakukan pada Bidang Hukum Kantor Wilayah Kementrian Hukum dan Hak Asasi Manusia di setiap lbukota Propinsi, dalam hal ini adalah Seksi Pelayanan dan Jasa. Hukum.

Pembebanan jaminan fidusia dilakukan melalui dua tahap yaitu :

Tahap pembebanan dan tahap pendaftaran jaminan fidusia. Dalam Pasal 5 (1) Undang-Undang Nomor 43 Tahun 1999 Tentang Fidusia dinyatakan :

"Pembebanan benda dengan jaminan fidusia dibuat dengan Akta Notaris dalam bahasa Indonesia dan merupakan Akta jaminan Fidusia"

Akta Notaris merupakan salah satu wujud akta otentik sebagaimana dimaksud dalam Pasal 1868 KUH Perdata.

Tahap kedua dalam proses perjanjian jaminan fidusia ialah pemberian jaminan dalam bentuk akta notaris dan kewajiban mendaftarkan jaminan fidusia itu, tindakan tersebut untuk memenuhi salah satu asas dari perjanjian pembebanan beban dengan jaminan fidusia. adalah yaitu asas publisitas.

Dengan didaftarkannya jaminan fidusia maka asas publisitas terpenuhi sekaligus merupakan jaminan kepastian terhadap kreditor lainnya mengenai benda yang telah dibebani 


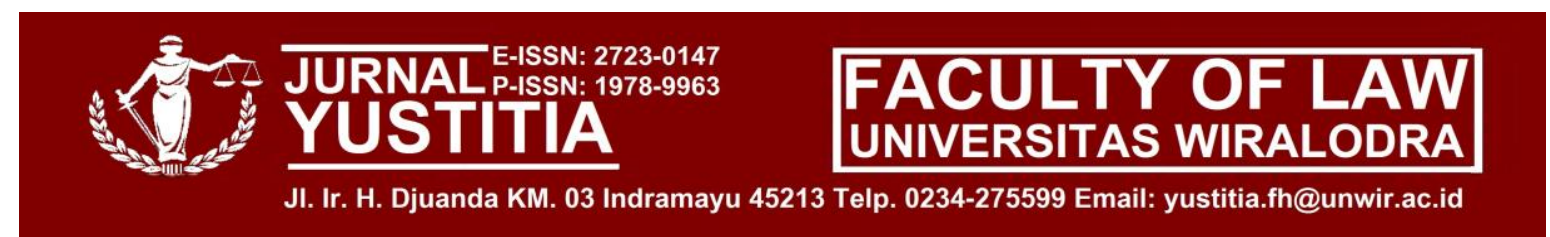

dengan jaminan fidusia ${ }^{11}$. Jaminan fidusia lahir pada. tanggal yang sama dengan tanggal dicatatnya jaminan fidusia dalam buku pendaftaran fidusia. Seperti yang dapat dilihat dalam skema di bawah ini :

Bandung, 5 Juli 2020, A meminjam uang kepada B

dengan Jaminan Fidusia sebuah Mobil Kijang Inova

Milik A

Bandung, 7 Juli 2020, A dan B membuat Akta Jaminan

Fidusia terhadap Pembebanan satu buah mobil Kijang

Inova dihadapan Notaris

Bandung, 8 Juli 2020, Oleh B sebagai penerima fidusia

Akta Notaris jaminan fidusia didaftarkan pada Kantor

Pendaftaran Fidusia di Kanwil Jawa Barat Kementrian

Hukum dan HAM

Dalam skema di atas, dijelaskan :

1. Pada bagian 1 debitor A dan kreditor B, melakukan kesepakatan berupa suatu utang piutang dengan pembebanan jaminan fiduasi terhadap harta benda milik debitor A berupa satu unit mobil Kijang.

2. Pada bagian 2, perjanjian utang piutang tersebut dengan jaminan fidusia, oleh debitor dan kreditor dibuatkan akta jaminan fidusia dihadapan Notaris, sebagaimana diamanatkan dalam Pasal 5 ayat 1 (1) UUJF, pada saat inilah tahap tahap pertama pembebanan fidusia dilakukan yaitu pada saat dibuatnya akta Notaris terhadap benda jaminan fidusia.

3. Pada bagian 3, merupakan pelaksanaan tahap kedua dari pembebanan jaminan fidusia pada tahap ini akta jaminan Fidusia yang dibuat oleh Notaris didaftarkan pada Kantor Pendaftaran Fidusia yang berada di lingkungan kerja Kanwil Kementrian Hukum dan HAM. Di masing-masing daerah. Pada tahap ini asas publisitas dianggap telah terlaksana dikarenakan daftar umum pendaftaran fidusia

\footnotetext{
${ }^{11}$ Gunawan Widjaja dan Ahmad Yani, Seri Hukum Bisnis Jaminan Fidusia, Raja Grafindo Persada, Jakarta, hlm. 135.
} 
terbuka bagi masyarakat luas untuk mengakses dan mengetahui benda-benda fidusia yang sudah dibebankan sebagai jaminan, dengan terselenggaranya asaspublisitas melalui pendaftaran ini maka pihak penerima fidusia dianggap sebagai kreditor preferent.

Berdasarkan penjelasan Pasal 11 Undang-Undang Nomor 43 Tahun 1999 Tentang Fidusia maka pendaftaran fidusia dilakukan pada tempat kedudukan si Pemberi Fidusia, tetapi masih banyak pemohon (Penerima Fidusia) yang mendaftarkan jaminan fidusia pada tempat berada benda yang akan dijaminkan. Hal ini yang menyebabkan beberapa permohonan pendaftaran pada Kantor Pendaftaran Fidusia ditolak dan disarankan untuk didaftarkan di Kantor Pendaftaran Fidusia tempat kedudukan si Pemberi Fidusia.

Dalam hal pendaftaran ini Kantor Pendaftaran Fidusia tidak boleh melakukan penelitian tentang kebenaran data yang tercantum dalam akta yang akan didaftarkan. Kantor Pendaftaran Fidusia hanya meneliti pada kelengkapan administrasi dan data yang akan dimohonkan.

Menurut Undang-Undang Nomor 43 Tahun 1999 Tentang Fidusia tata cara pendaftaran jaminan fidusia dilakukan oleh penerima fidusia di Kantor Pendaftaran Fidusia, permohonan pendaftaran jaminan fidusia oleh penerima fidusia, diatur lebih lanjut berdasarkan PP No. 86 Tahun 2000 tentang Tata Cara Pendaftaran jaminan Fidusia :

a. Permohonan pendaftaran fidusia dilakukan oleh penerima fidusia, kuasa atau wakilnya dengan melampirkan pemyataan pendaftaran jaminan fidusia yang memuat : (lihat contoh formulir pernyataan)

1) Identitas pihak pemberi fidusia dan penerima fidusia yang meliputi nama, tempat tinggal/tempat kedudukan, tempat dan tanggal lahir, jenis kelamin, status perkawinan, pekerjaan;

2) Tanggal dan nomor akta jaminan, nama dan tempat kedudukan notaris yang membuat akta, jaminan fidusia;

3) Data perjanjian pokok;

4) Uraian mengenai benda yang menjadi objek jaminan fidusia;

5) Nilai penjaminan;

6) Data Bukti hak (kepemilikan); dan

7) Nilai benda yang menjadi objek jaminan fidusia 


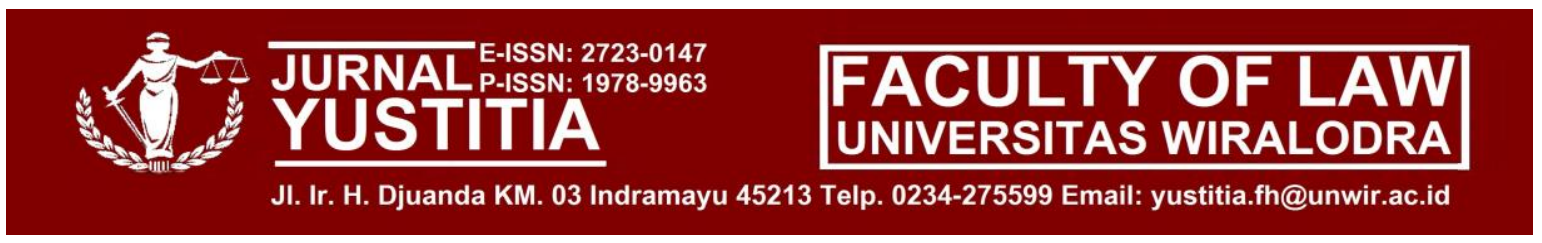

Pejabat Pendaftaran Jaminan Fidusia setelah menerima permohonan tersebut memeriksa kelengkapan persyaratan permohonan. Apabila tidak lengkap, harus langsung dikembalikan berkas permohonan tersebut.

b. Apabila sudah lengkap, Pejabat Pendaftaran Fidusia memberikan sertifikat jaminan fidusia dan menyerahkannya kepada pemohon yang dilakukan pada tanggal yang sama dengan tanggal pencatatan permohonan pendaftaran jaminan fidusia. Dalam praktek pelaksanaan penyerahan sertifikat fidusia ini dilakukan satu sampai dua mingggu dari tanggal pendaftaran, hal ini mengingat sarana dan prasarana yang sangat terbatas pada Kantor Pendaftaran Fidusia.

c. Apabila terdapat kekeliruan penulisan dalam sertifikat jaminan fidusia, dalam waktu 60 hari setelah menerima sertifikat jaminan fidusia pemohon memberitahu kepada Kantor Pendaftaran Fidusia untuk diterbitkan sertifikat perbaikan. Sertifikat jaminan fidusia ini memuat tanggal yang sama dengan tanggal sertifikat semula.

Pendaftaran jaminan fidusia akan memberikan informasi data-data baik mengenai ikatan jaminannya, maupun bendanya, karena dalam suatu pendaftaran fidusia semua hal tersebut dicatat dengan teliti oleh Kantor Pendaftaran Fidusia, sejalan dengan ketentuan dalam Pasal 13 Ayat (2) UUJF yang semuanya bertujuan untuk tercapainya kepastian hukum, dengan pendaftaran tersebut akan diketahui :
a. siapa para pihaknya;
b. perikatan pokok mana yang dijamin;
c. besamya utang;
d. besarnya beban jaminan;
e. data kepemilikan atas benda yang dijaminkan;
f. klausula-klausulanya.

Kesemuanya dicatat dengan rinci, benda jaminan juga dicatat dengan rinci, maka akan diperoleh manfaat sebagai berikut :

a. Pendaftaran benda, pemilik mempunyai bukti kepemilikan yang relatif pasti

b. Pendaftaran ikatan jaminan, kreditor punya bukti hak jaminan yang pasti; sertipikat jaminan fidusia memberikan alasan hak bagi kreditor. 
c. Pendaftaran benda, pihak ketiga tidak bisa lagi mengatakan bahwa ia tidak tahu siapa pemilik benda itu ; hat ini berkenan dengan adanya asas publisitas dalam pembebanan benda jaminan

d. Pendaftaran ikatan jaminan pihak ketiga tidak lagi mengemukakan bahwa ia tidak tahu barang benda tertentu, milik orang tertentu, sedang memikul beban jaminan untuk kreditor tertentu.

Dalam pelayanan permohonan Sertifikat Jaminan Fidusia, Kantor Pendaftaran Fidusia sering menerima permohonan sebagai berikut :

- Tempat kedudukan Pemberi Fidusia tidak termasuk dalam wilayah Kantor Pendaftaran Fidusia (sesuai penjelasan Pasal 11 UUJF tempat pendaftaran adalah sesuai dengan tempat kedudukan si Pemberi Fidusia);

- Dalam pemyataan pendaftaran fidusia tidak tercantum data hutang pokoknya (demikian juga dalam akta notaris yang dijadikan dasar pendaftaran). Menurut penjelasan notaris sebagai pihak yang diberi kuasa oleh Bank sebagai pemohon, ada beberapa pemohon (bank) yang tidak ingin hutang pokoknya dicantumkan.

- Dalam hal jenis benda yang menjadi obyek jaminan masih banyak ditemukan beberapa penerima fidusia yang menerima benda obyek jaminan yang tidak mempunyai sifat kebendaan itu sendiri, misalnya obyek jaminan fidusia berupa terinin proyek. Ada juga pemohon yang mengajukan akta Cessie untuk dimintakan sertifikat jaminan fidusia' padahal akta Cessie hanya bisa digunakan untuk pengajuan perubahan sertifikat jaminan fidusia.

- Terjadinya fidusia ulang hanya karena sebetulnya materi yang diajukan adalah untuk Perubahan sertifikat, tetapi oleh penerima fidusia melalui kuasanya didaftarkan sebagai permohonan baru.

- Dalam hal pengajuan permohonan penghapusan/pencoretan tidak disertai surat pernyataan (sesuai Pasal 25 UUJF) dari Penerima Fidusia.

Dengan didaftamya akta perjanjian fidusia, maka Kantor Pendaftaran Fidusia akan mencatat akta jaminan fidusia dalam Buku Daftar Fidusia dan kepada kreditor diberikan Sertifikat jaminan Fidusia. Saat pendaftaran akta pembebanan fidusia adalah melahirkan jaminan fidusia bagi pemberi fidusia, memberikan kepastian kepada kreditor lain mengenai benda yang telah dibebani jaminan fidusia dan memberikan hak yang didahulukan terhadap 
kreditor dan untuk memenuhi asas publisitas karena Kantor Pendaftaran Fidusia terbuka untuk umum.

Jika terjadi perubahan atas data yang tercantum dalam Sertifikat jaminan Fidusia, maka penerima fidusia wajib mengajukan permohonan pendaftaran atas perubahan tersebut ke Kantor Pendaftaran Fidusia. Setelah syarat-syarat kelengkapan administrasi dipenuhi maka Kantor Pendaftaran jaminan Fidusia mengeluarkan satu Sertifikat jaminan Fidusia untuk si pemohon (Penerima Fidusia) dan satu Buku Daftar Fidusia untuk disimpan di Kantor Pendaftaran Fidusia. Suatu yang sangat menguntungkan bagi kreditor penerima jaminan fidusia adalah bahwa Sertifikat jaminan Fidusia mengandung kata-kata yang biasa disebut irah-irah, "DEMI BERDASARKAN KETUHANAN YANG MAHA ESA", sebagaimana ketentuan dalam Pasal 15 ayat (1) Undang-Undang Nomor 43 Tahun 1999 Tentang Fidusia.

Pendaftaran fidusia secara langsung memberikan hak preferen terhadap kreditor untuk pelunasan terlebih dahulu atas piutangnya, hal yang perlu diingat terhadap perlindungan hukum demikian tidak dapat dimiliki oleh kreditor apabila perjanjian jaminan fidusianya tidak didaftarkan di kantor Pendaftaran Fidusia. Terhadap hal ini ada beberapa komentar yang perlu dijadikan koreksi:

1) Ada sebagian pelaku bisnis yang merasa keberatan dengan diadakannya pendaftaran fidusia ini, keberatan ini berkaitan dengan masih banyaknya nilai jaminan di bawah Rp50.000.000,00 (lima puluh juta rupiah), nilai jaminan yang kecil ini sangat memberatkan pihak pemberi fidusia (sebagai debitor), karena segala sesuatu biaya yang timbul atas adanya pendaftaran ini menjadi tanggungan si pemberi fidusia atau debitor sehingga banyak penerima fidusia untuk jaminan fidusia dengan nilai dibawah Rp.50.000.000,00 (lima puluh juta rupiah) tidak didaftarkan (kebanyakan dari BPR-Bank Perkreditan Rakyat);

2) Tempat pendaftaran yang hanya ada di Ibukota Propinsi, sangat menyulitkan bagi pemohon yang kedudukannya jauh dari Ibukota Propinsi, hat ini menyangkut biaya transportasi untuk menjangkau tempat pendaftaran, oleh karena itu banyak pemohon yang menginginkan untuk dibukanya Kantor Pendaftaran Fidusia di setiap Daerah Tingkat II (Kabupaten/Kota) sehingga biayanya menjadi lebih murah. 
B. Hambatan-hambatan dan Upaya Penyelesaian Dalam Pelaksanaan Perjanjian

\section{Kredit dengan Jaminan Fidusia}

Bahwa hambatan utama dari pelaksanaan perjanjian kredit dengan Jaminan Fidusia muncul ketika terjadi wanprestasi dari pihak debitor, yang disebabkan oleh berbagai faktor:

1. Usaha debitor mengalami kegagalan;

2. Kredit yang disalurkan tidak dipergunakan sebagaimana mestinya (tidak sesuai dengan tujuan pengajuan kredit) oleh debitor;

3. Debitor tidak beritikad baik untuk memenuhi kewajibannya;

4. Keadaan perekonomian secara nasional yang juga membawa pengaruh terhadap kondisi keuangan debitor;

5. Hal-hal lain yang diluar prediksi.

Dalam kondisi tersebut upaya eksekusi merupakan upaya yang harus dilakukan untuk menyelamatkan kredit yang telah disalurkan agar tidak menjadi Non Performance Loans (NPL) bagi pihak bank. Upaya eksekusi merupakan upaya terakhir yang ditempuh setelah upaya restrukturisasi dan upaya pendekatan secara musyawarah mufakat gagal dilakukan.

Namun dalam prakteknya terdapat beberapa kendala dalam melakukan eksekusi jaminan fidusia, yaitu:

1. Sita eksekusi tidak dapat diletakkan pada Objek jaminan fidusia Meskipun Pasal 23 ayat (2) Undang-Undang Nomor 42 Tahun 1999 tentang Jaminan Fidusia, menentukan bahwa pemberi fidusia dilarang mengalihkan, menggadaikan atau menyewakan objek jaminan fidusia kecuali dengan persetujuan tertulis lebih dahulu dari penerima-fidusia. Namun dalam prakteknya timbul suatu permasalahan, dalam hal pemegang jaminan fidusia mohon sita eksekusi terhadap objek fidusia ternyata objek jaminan fidusia tersebut telah dibeli oleh pihak ketiga secara beritikad baik, pihak ketiga tersebut berdasarkan Pasal 1977 KUHPerdata dapat percaya bahwa barang bergerak orang yang menguasai (membezit) barang tersebut adalah pemiliknya (bezit geldt als volkomen title).

2. Merupakan suatu kendala bagi bank selaku kreditor pemegang fidusia dalam hal akan menjual objek jaminan fidusia melalui mekanisme menjual atas kekuasaan sendiri dengan mohon bantuan Kantor Lelang/Balai Lelang untuk menjual objek jaminan fidusia sesuai dengan bunyi Pasal 15 ayat (3) Undang- Undang Jaminan 
Fidusia, akan tetapi barang yang menjadi objek jaminan fidusia tidak diketemukan atau dikuasai oleh orang lain, dalam hal ini tentunya Kantor Lelang/Balai Lelang tidak dapat melakukan penjualan lelang objek fidusia tersebut.

3. Objek Jaminan Fidusia Hilang.

Apabila kita cermati lebih lanjut ketentuan Pasal 15 ayat (2) Undang-Undang Jaminan Fidusia, yang mengatakan sebagai berikut :

"Sertifikat jaminan fidusia sebagaimana dimaksud dalam ayat (1) mempunyai kekuatan eksekutorial yang sama dengan putusan pengadilan yang telah memperoleh kekuatan hukum pasti”.

4. Objek jaminan telah beralih/dijual kepada pihak ketiga lainnya

5. Objek jaminan sudah tidak ada/hilang.

6. Objek jaminan telah berubah bentuk

7. Objek jaminan tagihan yang hanya merupakan daftar/surat pernyataan pemberian fidusia yang tidak terinformasikan dasar- dasar penerbitannya tidak dapat dilakukan eksekusinya.

Kekuatan eksekutorial sebagaimana dimaksudkan pada Pasal 15 ayat (2) UndangUndang Nomor 42 Tahun 1999 tersebut adalah langsung dapat dilaksanakan tanpa melalui Pengadilan Negeri dan bersifat final serta mengikat para pihak untuk melaksanakan putusan tersebut. Terhadap peiaksanaan eksekusi putusan pengadilan yang telah memperoleh kekuatan hukum tetap harus mengacu pada ketentuan Pasal 195 HIR dan selanjutnya, artinya bahwa eksekusi putusan pengadilan yang telah memperoleh kekuatan hukum tetap dan bersifat serta merta harus dilakukan di bawah pimpinan Ketua Pengadilan Negeri yang berwenang. Oleh karena Pasal 15 ayat (2) Undang-Undang Nomor. 42 Tahun 1999 menyebutkan sertifikat jaminan fidusia yang berisikan irah-irah "Demi Keadilan Berdasarkan Ketuhanan Yang Maha Esa" mampunyai kekuatan hukum eksekutorial yang sama dengan putusan pengadiian yang telah memperoleh kekuatan hukum tetap, maka eksekusi sertifikat jaminan fidusia yang berjudul "Demi Keadilan Berdasarkan Ketuhanan Yang Maha Esa" juga harus di bawah pimpinan Ketua Pengadilan Negeri yang berwenang. Sebagaimana diketahui, proses eksekusi suatu putusan yang telah memperoleh kekuatan hukum tetap atau yang bersifat serta merta termasuk proses eksekusi sertifikat jaminan 
fldusia/hak tanggungan yang berjudul "Demi Keadilan Berdasarkan Ketuhanan Yang Maha Esa" mempunyai 3 (tiga) tahapan, yaitu :

1. Tahap peneguran, pada tahap ini debitor yang cidera janji diperingatkan untuk memenuhi kewajiban membayar utang dalam jangka waktu 8 (delapan) hari setelah diberi peneguran;

2. Tahap sita eksekusi, dalam hat debitor dalam jangka 8 (delapan) hari tersebut di atas, tidak juga memenuhi kewajibannya membayar hutang kepada kreditor, maka kreditor pemohon eksekusi (penggugat pemenang perkara atau kreditor pemegang hak tanggungan/kreditor pemenang jaminan fidusia) mohon kepada Ketua Pengadilan yang berwenang untuk melakukan sita eksekusi. Dalam hal pemohon eksekusi adalah pemegang sertifikat jaminan fidusia atau pemegang hak tanggungan yang dirnohonkan sita eksekusi adalah objek jaminan fidusia, objek hak tanggungan. Atas permohonan sita eksekusi tersebut Ketua Pengadilan yang berwenang akan menerbitkan sita eksekusi dan kemudian jurusita melakukan sita eksekusi.

3. Tahap pelelangan, dalam hal setelah dilakukan sita eksekusi terhadap hak tanggungan atau objek fidusia (barang jaminan) debitor tetap tidak membayar hutangnya, maka atas permohonan pemohon eksekusi (kreditor pemegang sertifikat hak tanggungan atau sertifikat fidusia) Pengadilan yang berwenang akan menerbitkan penetapan pelelangan/penjualan umum, baru kemudian Kantor Lelang Negara akan melakukan pelelangan objek jaminan hak tanggungan atau objek fldusia. Tentunya setelah semua persyaratan yang diperlukan dipenuhi dan hasil penjualan lelang tersebut setelah dipenuhi dan hasil penjualan lelang tersebut setelah dikurangi biaya lelang dan biaya lain- lain diserahkan kepada kreditor pemohon eksekusi. Dalam hal ada sisa hasil penjualan lelang, tersebut harus diserahkan kembali kepada debitor.

Namun dalam praktiknya hal tersebut ternyata belum dapat dijadikan suatu upaya hukum yang efisien dalam melakukan eksekusi jaminan fidusia, mengingat permohonan eksekusi melalui title eksekutorial tersebut memerlukan rentang waktu yang cukup panjang dan membutuhkan biaya yang cukup besar. Sehingga proses eksekusi yang sederhana, cepat, murah dan efesien masih diperlukan dewasa ini bagi dunia perbankan. 


\section{PENUTUP}

\section{A. Simpulan}

1. Jaminan Fidusia merupakan perjanjian accesoir dari perjanjian pokoknya yaitu perjanjian kredit. Pembebanan Jaminan Fidusia dibuat dalam bentuk akta otentik/notariil dan berbahasa Indonesia. Untuk menjamin kepastian hukum dari pembebanan jaminan fidusia maka akta perjanjian jaminan fidusia tersebut selalu di daftarkan ke kantor Pendaftaran Fidusia untuk dapat diterbitkannya Sertipikat Jaminan Fidusia yang mempunyai kekuatan eksekutorial.

2. Hambatan utama dari pelaksanaan perjanjian kredit dengan Jaminan Fidusia muncul ketika terjadi waprestasi dari pihak debitor, yang disebabkan oleh berbagai faktor. Dalam kondisi tersebut upaya eksekusi merupakan upaya yang harus dilakukan untuk menyelamatkan kredit yang telah disalurkan Namun dalam prakteknya terdapat beberapa kendala dalam melakukan eksekusi jaminan fidusia, yaitu:

a. Sita eksekusi tidak dapat diletakkan pada Objek jaminan fidusia

b. Merupakan suatu kendala bagi bank selaku kreditor pemegang fidusia dalam hal akan menjual objek jaminan fidusia melalui mekanisme menjual atas kekuasaan sendiri dengan mohon bantuan Kantor Lelang/Balai Lelang untuk menjual objek jaminan fidusia sesuai dengan bunyi Pasal 15 ayat (3) Undang-Undang Jaminan Fidusia, akan tetapi barang yang menjadi objek jaminan fidusia tidak diketemukan atau dikuasai oleh orang lain, dalam hal ini tentunya Kantor Lelang/Balai Lelang tidak dapat melakukan penjualan lelang objek fidusia tersebut.

c. Objek Jaminan Fidusia Hilang.

\section{B. Saran}

Perjanjian kredit, perlu memperoleh perhatian yang khusus baik oleh bank sebagai kreditor maupun oleh nasabah sebagai debitor, karena perjanjian kredit mempunyai fungsi yang sangat penting dalam pemberian, pengelolaan dan 
penatalaksanaan kredit tersebut. Di masa mendatang diperlukannya suatu peraturan perundang-undangan yang lengkap tentang pelaksanaan eksekusi jaminan di Indonesia, sehingga proses eksekusi yang sederhana, cepat, murah dan efesien dapat diwujudkan.

\section{DAFTAR PUSTAKA}

\section{A. Buku :}

A. Hamzah \& Senjun Manulung, Lembaga Fidusia dan Penerapannya di Indonesia, Indhill-Co, Jakarta, 1987.

Amirudin “et.al” Pengantar Metode Penelitian Hukum, Raja Grafindo Persada, Jakarta, 2000 .

Gunawan Widjaja dan Ahmad Yani, Seri Hukum Bisnis Jaminan Fidusia, Raja Grafindo Persada, Jakarta

Kashadi, Hukum Jaminan, Fakultas Hukum Universitas Diponegoro, Semarang, 2000

Muhammad Djumhana, Hukum Perbankan di Indonesia, Citra Aditya Bakti, Bandung. 1998

Munir Fuady, Jaminan Fidusia, PT. Citra Aditya Bakti. Bandung, 2000

Purwahid Patrik dan Kashadi, Hukum Jaminan Edisi Revisi dengan UUHT, Fakultas Hukum Universitas Diponegoro, Semarang, 1997

Ronny Hanitijo Soemitro, Metodologi Penelitian Hukum dan Jurimetri, Galia Indonesia, cet. ke-4, Jakarta, 1990

Soerjono Soekanto, Pengantar Penelitian Hukum, Grafindo, Jakarta, 2006, hlm 10.

Sri Soedewi Masjchun, Hukum Jaminan di Indonesia Pokok-pokok Hukum Jaminan dan Jaminan Perorangan, Liberty, Yogyakarta, 1980

Sunaryati Hartono, "Kembali ke Metode Penelitian Hukum", dalam Bunga Rampai Metodologi Penelitian dan Penulisan Karya Ilmiah Hukum, Koko Kosidin (Ed), 1990, hlm. 4. 